\title{
River restoration challenges with a specific view on hydromorphology
}

\author{
Jianhua LI ${ }^{\mathrm{a}}$, Stephan HOERBINGER ${ }^{\mathrm{b}}$, Clemens WEISSTEINER ${ }^{\mathrm{c}}$, Lingmin PENG ${ }^{\mathrm{a}}$, Hans Peter RAUCH ${ }^{\mathrm{b}, \mathrm{c}^{*}}$ \\ ${ }^{a}$ Key Laboratory of Yangtze River Water Environment, Tongji University, Shanghai 100029, China \\ ${ }^{b}$ Institute of Soil Bioengineering and Landscape Construction, University of Natural Resources and Life Sciences, Vienna, Austria \\ ${ }^{c}$ GeoVerde OG, Landscape Engineers, Vienna, Austria \\ *Corresponding author.E-mail: hp.rauch@boku.ac.at
}

(C) The Author(s) 2020, corrected publication 2020. This article is published with open access at link.springer.com and journal.hep.com.cn 2020

\section{Introduction}

\subsection{River ecosystem degradation}

Over the past century, almost throughout the whole world, streams and rivers have been heavily polluted and morphologically degraded due to industrial, household and agricultural sources, leading to significant declines in biodiversity, water quality and ultimately water supply [15]. In the last decades, river system design has been practiced from an engineering viewpoint that focuses on water abstraction, sanitation, generation of energy, transportation and safety, rather than from a socio-ecological perspective. The technical management altered the understanding of a functioning river system itself and its social context. This strongly modified the physical and cultural nexus between rivers and the nearby human population [6]. Individual or combined effects of stressors usually lead to a reduction in biodiversity due to reduced water quality, habitat degradation, dispersal barriers, unsuitable biological flow regimes, changes in the input of organic matter or sunlight, etc.[7]. Given the importance of freshwater systems in providing ecological services and diverse habitats for many species, it is clear that restoration is needed to maintain sustainable ecological services while restoring ecosystem function and habitat scope [8].

\subsection{Hydromorphology came into being}

The insight that a restored river ecosystem can deliver multiple interconnected benefits to society has led to a

Article history: Received Feb 29, 2020; Accepted Jul 22, 2020 change in the perception of functional river systems and to an expansion of river restoration [9]. The Water Framework Directive (200/60/EC, WFD) and the US Clean Water Act (US CWA) emerged as a formalized demand for healthy freshwater ecosystems and acts as a catalyst for river restoration projects, consequently meeting the implementation of upcoming directives like the UN' sustainable development goals (SDGs). A universal river restoration approach includes a wide range of possible target issues. In a first step the solution of a water pollution problem is a key issue of river restoration projects. Also, human activities. Besides that, human activities have a huge impact on the hydromorphlogical conditions of rivers. Therefore, hydromorphology is one key discipline in river restoration projects. Hydromorphology combines the disciplines of hydrology and geomorphology in order to classify both jointly for stream conditions [10].

Over the past 40 years, the destruction of the physical habitat of river ecosystem is especially serious due to the rapid urbanization speed in China, however, due to the huge pressure to face the increasing water pollution and frequent floods at the same time, river management still mainly concentrated in the flood control and water conservancy infrastructure construction and water environmental pollution control, and even many river regulation and flood control projects themselves have exacerbated the river ecosystem physical habitat destruction. It is necessary to learn from the lessons of developed countries and formulate the physical river habitat protection policy as early as possible, to reverse the declining physical habitat quality of river ecosystem, examine and develop hydromorphology, an emerging discipline in river ecosystem restoration practice. 


\section{Application in river restoration}

River hydromorphology represents physical structures and dynamics of rivers which is useful for establishing links between physical and biological conditions [11]. Within the WFD hydromorphology plays an important role to assess and support an integrated management of river systems. By means of hydromorphological assessments, large-scale processes and channel dynamics can be integrated in the planning of restoration projects. Furthermore, it provides the foundation for the evaluation of ecological responses to restoration measures. In this context the WFD is acting as a catalyst for hydromorphological assessment methods in countries of the European Union. With the implementation of the WFD in national law each member state developed one or more approaches to assess hydromorphological parameters. Belletti et al. [12] mentions in their review on existing hydromorphological methods a shift from approaches focusing mainly on occurrence and spatial configuration of habitats in the end of the 20th century to broader river condition assessments including pressure and response variables focusing more on dynamics and processes.

\subsection{Hydromorphological assessment method}

Current hydromorphological assessment methods can be distinguished in 4 main approaches: 1) physical habitat assessment, 2) riparian habitat assessment, 3) morphological assessment, 4) hydrological stream alteration [13]. All 4 approaches have different backgrounds and have been developed with certain aims. Physical habitat assessment methods are the most common approach and focus mainly on the presence and characteristics of physical habitats [12]. From a spatial context, they are applied in site to reach scale, laterally some methods are confined by the channel width most of them include riverbanks and some methods are extended to the whole floodplain [14]. However, historical evolution of the assessed river is seldom taken into account in this method [12]. It is important to understand biological-physical feedbacks in rivers. This applies to physical changes on microhabitat scale where, i.e., the properties of substrate and the pool/riffle system due to the variations of runoff and sediment transport is a relatively fast response of hydromorphology in a smaller spatial and temporal scale. And this applies to geomorphological change in a larger spatial and temporal scale, which can give more mechanism explanations, i.e., the cause-effect relationship. Riparian habitat methods focus mainly on the riparian zone and vegetation, some of these methods include also channel features. The integration of vegetation in the assessment of the river status links physical features with biota. Structures of the riparian zone represent main hydromorphological elements supporting the biological communities at different scales [15]. Both methods (physical and riparian habitat method) are focusing mainly on the actual state on a small scale and are highly time consuming due to extended field work. A lack of both methods is a poor consideration of the involved processes and the causes of the alteration at a larger scale [13]. The morphological assessment method is strongly based on a geomorphological approach [12]. The focus of this approach is not pointing on providing information on the current status of a river but on measuring both "pressure" and "response" variables and provide the means to develop a clear understanding of cause-effect relationship that regulate the system response [16]. The approach is including a larger time scale approach and is applied mostly on a reach scale. This would imply repeated assessments at different times of the year and further which is unlikely to handle within a rapid hydromorphological assessment. Thus, recorded indicators are often generated from a static visual assessment of the presence of processes [12]. The same authors mention that morphological assessment methods have the limitation that generally physical processes are hard to assess properly and that parameters as the vertical connection to the groundwater or the consideration of habitats are not explicitly included within these methods. Methods for the assessment of hydrological regime alteration are based on producing hydrological assessment data, especially focusing on hydrologic alterations [17]. Hughes et al. [18] suggests that reference system need to be carefully used with six reasons: 1) there is usually no proper reference system to use, 2) since the selection of the historical reference system, many watershed parameters have changed, 3) climate change has been continuous throughout the Holocene, 4) projected climate change is of uncertain magnitude, 5) alien species cannot be avoided, 6) landscape changes in the environment. The need of long time series which not always are available are a downside of these methods. Furthermore, the definition of reference conditions is critical if not enough long-time scales are present. However, reference conditions can support the understanding of pristine ecosystem states and guide our management that to what extent the river system should be restored, i.e., a balance of the restoration efforts and the societal and ecological functions.

\subsection{The development of hydromorphological assessment}

There has been an evident trend over the past few years to increase the scientific development of geomorphologybased approaches to attempt to understand the function and evolution of rivers as a basis for interpreting the current conditions [19]. A new approach was developed by Rinaldi et al. [19] first for application in Italy and then adapted to the European framework. This approach (Morphological Quality Index) can be classified as a "process-based" 
method, which is embedded in an overall hierarchical open-ended framework [20]. The hydromorphological assessment proposed by Rinaldi et al. $[19,21]$ provides a flexible set of procedures, with four main stages:

1) catchment-wide delineation and spatial characterization;

2) assessment of temporal changes and current conditions;

3) assessment of scenario based future trends;

4) identification of management actions.

The approach described by Rinaldi et al. $[19,21]$ was developed and tested within a research project and is embedded in a wider hydromorphological framework [22]. The framework incorporates the morphological characteristics of the channel and its corridors into a larger spatial and temporal assessment of the dynamic control of the reach, as well as a process-based interpretation of the current status, historical dynamics and possible future trajectory of the reach [21]. Stage 2 of the approach (assessment of temporal changes and current conditions) is focusing on the hydromorphological assessment of the river reaches which is assessed by the Morphological Quality Index. It is based on three main components: artificiality, geomorphic functionality and channel adjustment, whereby indicators of artificiality can be seen as "pressure" and indicators of geomorphic functionality and channel adjustment can be seen as "response" indicators [13]. The MQI approach is based on an expert's judgement, expecting from the user specific knowledge and experience. It is designed to be relatively simple and not excessively time consuming. The approach is based on the consideration of processes and is aiming to assess morphological quality, including explicitly temporal components by specific indicators. Reference conditions are defined within the approach on dynamic processes and functions that are expected to normally occur in a given physical context. The key scale of the approach is the river reach, which can be delineated as follows: general identification and setting of landscape units as well as fragments; confinement typologies definition; scope of identification of morphological types and consideration of other factors. The Morphological Quality Index consists of 28 indicators, divided into three main components: geomorphologic function, channel and artificiality adjustment. This approach seeks to provide a comprehensive and overall assessment of river condition to facilitate an understanding of stress and response conditions (i.e., cause and effect), thus supporting the identification of possible management operations [19].

River restoration focuses on a reestablishment of specific river-type conditions, where different processes are induced to a state of dynamic equilibrium, reflecting the characteristic structure, processes and functions of similar river/river types with only slight human influence, at least in accordance with the "good ecological and chemical state" required by the WFD. River restoration therefore refers to measures that incorporate river morphology and hydrology as key components, as well as measures linked to land-use practices and spatial planning [4].

Restoration of rivers must be undertaken within the context of the suite of local and landscape factors that drive instream conditions. Loss of habitat for fishes, invertebrates and macrophytes and morphology sediment regime are strongly influenced by urbanisation and climate changes. Within the scope of a river restoration project, all of the above-mentioned modified conditions have to be taken into account. The Society for Ecological Restoration (SER 2004) identified key attributes of successful restoration that fall into four main categories: 1) ecosystem stability, 2) ecosystem function, 3) species composition, 4) landscape context. It further defined potential indicators for each category that could be used to assess the outcome of projects in the field [23]. Several studies have proven that river restoration projects can lead to an improvement of the morphological river condition but not from a biotic point of view [7]. Various reasons where found, e.g., still polluted rivers by the surroundings, or too little time has passed since the restoration, so there exist still open research questions why certain restoration activities didn't reach their goals. Deffner and Haase [24] also highlight the need to include social aspects in restoration projects in order to create acceptance and understand societal relation to the nature and to include this relation in the planning process.

Gurnell et al. [20] propose a broader view of urban river restoration by evaluating possible ecosystem service potentials and highlight the need of internalising the ecosystem service approach in a readily-used planning tool. For urban rivers, Francis suggests enhancing ecological function alongside novel conditions, rather than by trying to return urbanized rivers to their previous state [25]. This fundamental change in state is extremely difficult to reverse while maintaining the societal function of the system. The concept of "reference conditions" as expressed by the WFD is static and does not fully recognize the dynamic nature of river systems at multiple spatial and temporal scales [26]. This is particularly true for urban river systems, demanding a novel ecological modeling approach that is based on a sound scientific understanding of the effects of combination of stressors.

\subsection{Practical application in East Tiaoxi River and Nanxi River}

Experts from Tongji University (Water Ecology Laboratory) and Kyushu University (Japan, river research laboratory) conducted ecological health assessment of inflowing rivers in the Taihu Lake Basin (Fig. 3), sinoJapanese joint research team identified 84 species of fish 
through the comprehensive evaluation of the biggest intolake river East Tiaoxi River in Taihu Lake Basin [27], the evaluation results show that in the natural reach with less human intervention, the hydrogeomorphic diversity was significantly positively correlated with the habitat and fish diversity. The habitat diversity index increased with the increase of the river width-depth ratio (Fig. 1), and the fish diversity increased with the increase of the habitat diversity index (Fig. 2).

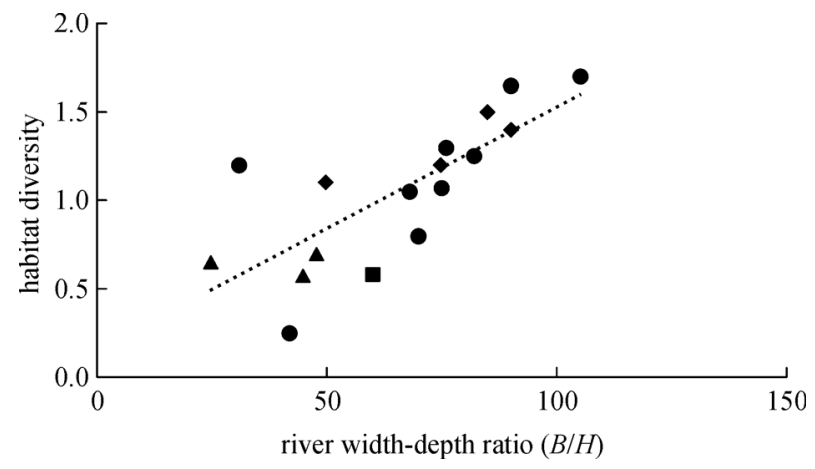

Fig. 1 Correlations between river width-depth ratio and habitat diversity.

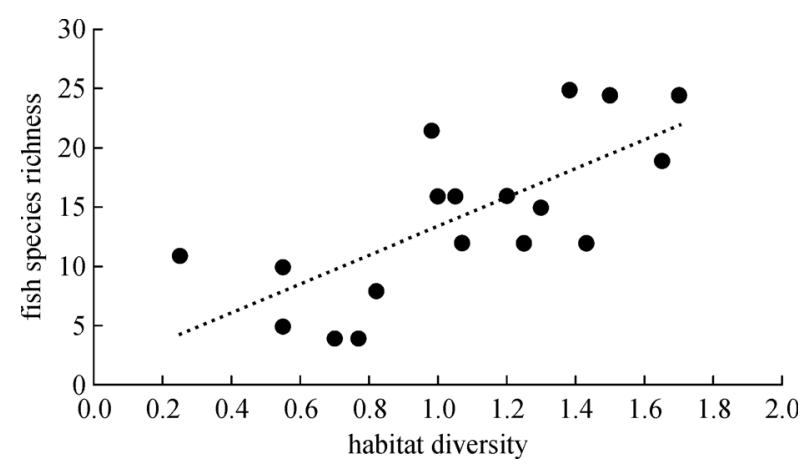

Fig. 2 Correlations between habitat diversity and fish species richness.
The Nanxi River is located in the river basin along the south-east coast of China, the basin area is $2436 \mathrm{~km}^{2}$ (including $2223 \mathrm{~km}^{2}$ in Yongjia county, accounting for $91.2 \%$ ), and the mainstream river length is $142 \mathrm{~km}$, with an average gradient of $6.0 \%$. The sino-European team carried out a joint survey on the Nanxi River since 2018 (Fig. 3), using 5 specific indicators from the MQI to assess the rivers morphological quality, which include Crosssection Configuration, Bed structure and substrate, vegetation and Interventions of maintenance and removal, and found that the hydrogeomorphic diversity played an important role in maintaining the river ecosystem function and protecting the aquatic biodiversity of the river. Benthic fauna and fish were in good condition.

\section{Discussions}

Despite much research on river systems over the last decade, critical questions remain to be resolved [25,28]. We lack an understanding of the mechanisms involved in linking rivers to the larger landscape and fundamental knowledge of urban aquatic ecology [25]. Knowledge gaps exist in aquatic habitat restoration in particular. The field of engineering disciplines can support the environmental restoration work in different ways. For example, at present China mainly focuses on pollution control of surface and groundwater. A high developed information technology and artificial intelligence technology provide automatic measurements, automatic sample collection, automatic water-quality-monitoring systems, automatic algae filtering and cleaning systems, and autonomous navigation for surface garbage cleaning and surface cleaning robots [29]. The results are most important first steps for river restoration and they provide a large-scale data basis for a sustainable integration of the ecological improvements. Further research should provide a clearer view of the outcomes of restoration measures based on pre- and postproject analysis [28]. Hydromorphological restoration that

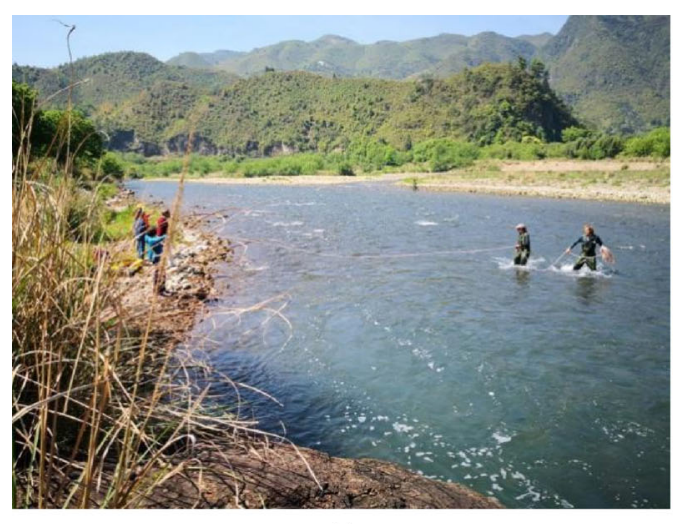

(a)

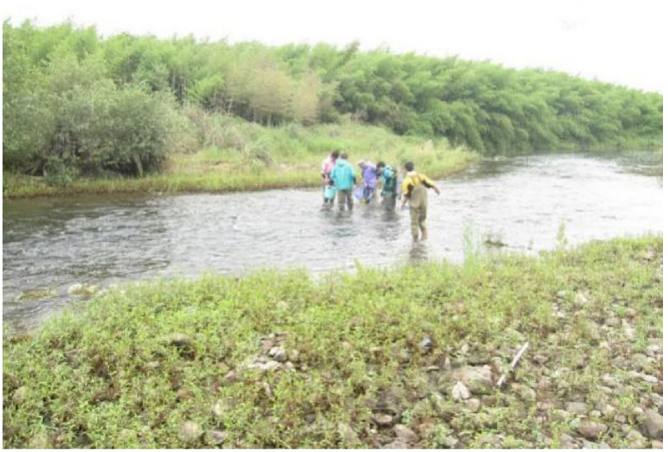

(b)

Fig. 3 Hydromorphological assessment in (a) Nanxi River and (b) East Tiaoxi River 
aims to improve the ecological status of river systems is often rather limited in scope and scale.

The socio-ecological approach we propose for urban rivers is based on the dynamic structure of river systems and incorporates societal, physical, chemical, biotic factors as well as their cumulative, antagonistic and synergistic effects. It also needs to be explored in future practice.

Open Access This article is licensed under a Creative Commons Attribution 4.0 International License, which permits use, sharing, adaptation, distribution and reproduction in any medium or format, as long as you give appropriate credit to the original author(s) and the source, provide a link to the Creative Commons licence, and indicate if changes were made.

The images or other third party material in this article are included in the article's Creative Commons licence, unless indicated otherwise in a credit line to the material. If material is not included in the article's Creative Commons licence and your intended use is not permitted by statutory regulation or exceeds the permitted use, you will need to obtain permission directly from the copyright holder.

To view a copy of this licence, visit http://creativecommons.org/licenses/ by $/ 4.0 \%$.

Open access funding provided by University of Natural Resources and Life Sciences Vienna (BOKU).

\section{References}

1. Everard M, Moggridge H L. Rediscovering the value of urban rivers. Urban Ecosystems, 2012, 15(2): 293-314

2. WWF. Living Planet Report-2018: Aiming Higher. Gland: WWF, 2018

3. Millennium Ecosystem Assessment. Ecosystems and Human Wellbeing: Synthesis. Washington, D.C.: Island Press, 2005

4. Roland P. River Ecosystem Management: Science for Governing Towards a Sustainable Future. Berlin: Springer Open, 2018

5. Strayer D L, Dudgeon D. Freshwater biodiversity conservation: recent progress and future challenges. Journal of the North American Benthological Society, 2010, 29(1): 344-358

6. Åberg E U, Tapsell S. Revisiting the River Skerne: The long-term social benefits of river rehabilitation. Landscape and Urban Planning, 2013, 113: 94-103

7. Palmer M A, Menninger H L, Bernhardt E. River restoration, habitat heterogeneity and biodiversity: A failure of theory or practice? Freshwater Biology, 2010, 55: 205-222

8. Giller P. River restoration: Seeking ecological standards. Editor's introduction. Journal of Applied Ecology, 2005, 42(2): 201-207

9. Bernhardt E S, Palmer M A. Restoring streams in an urbanizing world. Freshwater Biology, 2007, 52(4): 738-751

10. Gurnell A M, Corenblit D, García de Jalón D, González del Tánago M, Grabowski R C, O’Hare M T, Szewczyk M. A Conceptual model of vegetation-hydrogeomorphology interactions within river corridors. River Research and Applications, 2016, 32(2): 142-163

11. Belletti B, Rinaldi M, Bussettini M, Comiti F, Gurnell A M, Mao L, Nardi L, Vezza P. Characterising physical habitats and fluvial hydromorphology: A new system for the survey and classification of river geomorphic units. Geomorphology, 2017, 283: 143-157

12. Belletti B, Rinaldi M, Buijse A D, Gurnell A M, Mosselman E. A review of assessment methods for river hydromorphology. Environmental Earth Sciences, 2015, 73(5): 2019-2100
13. Rinaldi M, Surian N, Comiti F, Bussettini M, Belletti B, Nardi L, Lastoria B, Golfieri B. Guidebook for the Evaluation of Stream Morphological Conditions by the Morphological Quality Index (MQI). Management, 2015

14. Fernández D, Barquin $\mathrm{J}$, Raven $\mathrm{P} \mathrm{J}$. A review of river habitat characterisation methods: Indices vs. characterisation protocols. Limnetica, 2011, 30(2): 217-234

15. González Del Tánago M, García De Jalón D. Riparian qualityindex (RQI): A methodology for characterizing and assessing environmental conditions of riparian zones. Limnetica, 2011, 30(2): 235254

16. Fryirs K A, Arthington A, Grove J. Principles of river condition assessment. In: Brierley G, Fryirs K A, eds. River Futures. An Integrative Scientific Approach to River Repair. Washington, D.C.: Society for Ecological Restoration International, Island Press, 2008, $100-124$

17. Poff N L, Allan J D, Palmer M A, Hart D D, Richter B D, Arthington A H, Rogers K H, Meyer J L, Stanford J A. River flows and water wars: Emerging science for environmental decision making. Frontiers in Ecology and the Environment, 2003, 1(6): 298-306

18. Hughes F M R, Colston A, Mountford J O. Restoring riparian ecosystems: the challenge of accommodating variability and designing restoration trajectories. Ecology and Society, 2005, 10(1): art 12

19. Rinaldi M, Belletti B, Bussettini M, Comiti F, Golfieri B, Lastoria B, Marchese E, Nardi L, Surian N. New tools for the hydromorphological assessment and monitoring of European streams. Journal of Environmental Management, 2017, 202: 363-378

20. Gurnell A, Lee M, Souch C. Urban Rivers: Hydrology, Geomorphology, Ecology and Opportunities for Change. Geography Compass, 2007, 1(5): 1118-1137

21. Rinaldi M, Gurnell A M, del Tánago M G, Bussettini M, Hendriks D. Classification of river morphology and hydrology to support management and restoration. Aquatic Sciences, 2016, 78(1): $17-33$

22. Gurnell A M, Rinaldi M, Belletti B, Bizzi S, Blamauer B, Braca G, Buijse A D, Bussettini M, Camenen B, Comiti F, Demarchi L, García De Jalón D, González Del Tánago M, Grabowski R, Gunn I, Habersack H, Hendriks D, Henshaw A, Klösch M, Lastoria B, Latapie A, Marcinkowski P, Martínez Fernández V, Mosselman E, Mountford J O, Nardi L, Okruszko T, O’Hare M T, Palma M, Percopo C, Surian N, van de Bund W, Weissteiner C, Ziliani L. A multiscale hierarchical framework for developing understanding of river behaviour to support river management. Aquatic Sciences, 2016, 78(1): 1-16

23. Palmer M, Hondula K, Koch B. Ecological restoration of streams and rivers: Shifting strategies and shifting goals. Annual Review of Ecology Evolution and Systematics, 2014, 45(1): 247-269

24. Deffner J, Haase P. The societal relevance of river restoration. Ecology and Society, 2018, 23(4): 35

25. Francis R. Urban rivers: Novel ecosystems, new challenges. WIREs. Water, 2014, 1(1): 19-29

26. Kondolf M, Zolezzi G. Reference river ecosystems: Historical states, best ecological potential and management challenges. Workshop summary. In: Proceedings of the IV ECRR. Venice, 
2008, 1059-1063

27. Nakajima J, Sato T, Huang L L, Li J H. Fishes of the East Tiaoxi River in Zhejiang Province, China. Ichthyological Exploration of Freshwaters, 2013, 23(4): 327-343

28. Moggridge H L, Hill M J, Wood P J. Urban aquatic ecosystems: The good, the bad and the ugly. Fundamental and Applied Limnology; Official Journal of the International Association of Theoretical and Applied Limnology, 2014, 185(1): 1-6

29. Engineering Fronts 2019. Center for Strategic Studies. Beijing: Chinese Academy of Engineering, 2019 